Article

\title{
Indoor Air Quality and Thermal Conditions in a Primary School with a Green Roof System
}

\author{
Nikolaos Barmparesos 1,*iD, Margarita Niki Assimakopoulos ${ }^{1}$, Vasiliki D. Assimakopoulos ${ }^{2}$, \\ Nikolaos Loumos ${ }^{1}$, Maria Aliki Sotiriou ${ }^{1}$ and Athanasios Koukoumtzis ${ }^{1}$ \\ 1 Department of Applied Physics, Faculty of Physics, University of Athens, Building Physics 5, \\ University Campus, 15784 Athens, Greece; masim@phys.uoa.gr (M.N.A.); \\ loumos_nick@hotmail.com (N.L.); avenir16@hotmail.com (M.A.S.); a.koukoumtzis@yahoo.com (A.K.) \\ 2 Institute for Environmental Research and Sustainable Development, National Observatory of Athens, \\ Lofos Koufou, 15236 Athens, Greece; vasiliki@noa.gr \\ * Correspondence: nikobar@phys.uoa.gr; Tel.: +30-210-727-6845
}

Received: 30 November 2017; Accepted: 17 February 2018; Published: 20 February 2018

\begin{abstract}
This paper presents experimental results from a typical school building in Athens, equipped partly with a green roof system (GRS). Environmental monitoring took place in six classrooms located both under the concrete roof and the GRS sectors as well as in the immediate external environment during the warm and cold periods of a school year. Daily measurements of pollutants $\mathrm{CO}_{2}$, TVOCs (Total Volatile Organic Compound), $\mathrm{PM}_{1}, \mathrm{PM}_{2.5}$, and $\mathrm{PM}_{10}$ were performed in selected classes. Moreover, indoor ambient temperature $(\mathrm{T})$ and relative humidity $(\mathrm{RH})$ measurements were implemented in order to estimate the absolute humidity $(\mathrm{AH})$ and assess the indoor environmental conditions. The results highlight that during summer, the GRS reduces temperature in a classroom on the top floor by about $2.8^{\circ} \mathrm{C}$, in comparison with the respective classroom under the concrete roof and that $\mathrm{AH}$ remained relatively stable for both classrooms. Amid winter, a reverse behavior occurs only for temperature. Moreover, air exchange rates (AER) were calculated by using the $\mathrm{CO}_{2}$ decay method for all of the classrooms. The results demonstrated insufficient ventilation for all experimental sights. Finally, concentrations of $\mathrm{PM}_{1}, \mathrm{PM}_{2.5}$ and $\mathrm{PM}_{10}$, were found to be relatively decreased, with average values of $0.79,3.39$, and $27.80 \mu \mathrm{g} \mathrm{m}^{-3}$. Levels of $\mathrm{CO}_{2}$ and TVOCs were elevated during class hours ranging from 469 to $779 \mathrm{ppm}$ and from $6.63 \mathrm{ppm}$ to $13.33 \mathrm{ppm}$, respectively, but generally within the respective limits of exposure. The examination of the indoor/outdoor (I/O) ratio of air pollutants, demonstrated that the outdoor meteorology affects only $\mathrm{PM}_{1}$ and $\mathrm{PM}_{2.5}$, as $\mathrm{PM}_{10}$ and TVOCs are strongly affected by internal sources and the activities of pupils.
\end{abstract}

Keywords: indoor air quality; thermal conditions; school building microenvironment; green roof; air pollutants

\section{Introduction}

Green roof system (GRS) can mitigate building's thermal load [1], reduce local $\mathrm{PM}_{10}$ concentrations [2] and improve the management of rainwater. It is a constructive innovation with many energy benefits that at the same time are accompanied by a considerable economic cost. Specifically, [3] and [4] highlight that along the economic aspect of maintenance, $\mathrm{CO}_{2}$ emissions as well as the energy balance of the building should be considered for each case. A study by [5] reports that white roofs have better results than conventional concrete ones, but in cases of electric heating of the building, the GRS has the second best performance. In Mediterranean climates, GRS cannot replace conventional insulation, but can lead to remarkable improvements in cooling of the building, thermal comfort of the inhabitants, and shading from sunlight [6]. Furthermore, the type of vegetation has a significant impact on the energy efficiency of a GRS and mainly on the emission of air pollutants. Best results are obtained, 
according to [7], by using vegetation with large leaf area index (LAI) and low stomatal resistance. Good indoor environmental conditions are crucial for spaces of special use, such as classrooms, as they help maintain a clean healthy environment for students and educational personnel. Recent studies by [8-12] found that ventilation, indoor sources, and the proximity to outdoor sources largely affect the indoor air quality. Studies by [13] and [14] demonstrated that GRS protect the roof structure under extreme temperature and large temperature fluctuations. They also showed that internal air temperature fluctuation is smaller under GRS during daytime. In [15], one may see that temperature over the GRS was lower by $3.7^{\circ} \mathrm{C}$ than the respective over a bitumen roof. Specifically, temperature range over the GRS was $23-36{ }^{\circ} \mathrm{C}$, while over the bitumen roof $32-44{ }^{\circ} \mathrm{C}$, respectively. The research of [16] reports less cases of overheating in a school building with GRS, as compared to regular roofs. Furthermore, [17] recorded $3-4{ }^{\circ} \mathrm{C}$ temperature drop under GRS, when outdoor temperature ranged between 25 and $30^{\circ} \mathrm{C}$.

The aim of this paper is to present the results of an experimental campaign that took place in a Greek primary school close to the center of Athens with an installed GRS. Only a part of the total roof surface is covered by vegetation and the rest of it consists of cement, which facilitates the direct comparison of results between the two types of roofs (reference area). Concentrations of the main air pollutants, as well as temperature and relative humidity were monitored within classrooms and on the roofs.

\section{Methodology}

The experimental campaign took place at the 2nd Primary School of Nea Smyrni, which is located in the southern suburbs of the Attica basin, close to the coastline of the Saronikos Gulf. The total area of the Nea Smyrni municipality is $3487 \mathrm{~km}^{2}$ and its population is 73,076 . It is a densely built residential area with highly trafficked streets. The sources of pollution are well distributed around the Nea Smyrni area combining traffic mainly from the central part of Athens (North), port activities form the Southwest (port of Piraeus), and central heating from nearby dwellings. The school (Figure 1) is a two storey building, nearby a busy street (location: $37^{\circ} 56^{\prime} 19.8^{\prime \prime} \mathrm{N}, 23^{\circ} 42^{\prime} 57.8^{\prime \prime} \mathrm{E}$ ). The GRS covers $1 / 3$ of the school's total roof area, while the rest is cement. The school complex was built successively in 1954 and 2000, while the green roof system was added in 2008. It is of an extensive type, lightweight (less than $150 \mathrm{~kg} / \mathrm{m}^{2}$ ), and covers an area of $374 \mathrm{~m}^{2}$. Its layers include the following from the roof top up: a root repelling membrane, a protective membrane, the drainage network, a non-permeable membrane, light soil of $150 \mathrm{~mm}$ thickness and low vegetation including herbaceous plants, grass, etc. The plants have minimum water requirements and are irrigated by an automatic watering system. The concrete roofs are of standard design and have a layer of reinforced concrete, covered with thermal insulation material and a sealing membrane.

The measurements extended from June to July 2016 (reference period after the end of the school year) and from October 2016 to June 2017. The instrumentation consisted of portable continuous recording equipment for Temperature (T) and Relative Humidity (RH) (Tinytag Plus 2 thermo-hygrometers with a recording range from -25 to $85^{\circ} \mathrm{C}$ for temperature and from 0 to $100 \%$ for relative humidity and accuracy of $\pm 0.6{ }^{\circ} \mathrm{C}$ and $\pm 3.0 \%$, respectively). Absolute humidity was calculated according to equation (1), as reported by [18]:

$$
\mathrm{AH}=\frac{6.112 \times \mathrm{e}^{\frac{17.67 \times \mathrm{T}}{\mathrm{T}+243.5} \times \mathrm{RH} \times 2.1674}}{273.15+\mathrm{T}}
$$

where, $\mathrm{T}$ is the temperature in ${ }^{\circ} \mathrm{C}$ and $\mathrm{RH}$ is relative humidity in $\%$. $\mathrm{AH}$ values are measured in

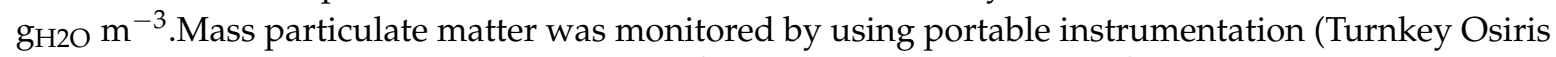
with a recording range from 0 to $6000 \mu \mathrm{g} \mathrm{m}^{-3}$ and accuracy of $0.1 \mu \mathrm{g} \mathrm{m}^{-3}$ and Lighthouse Handheld 3016 ranging from 0.3 to $25 \mu \mathrm{m}$, with counting efficiency $50 \%$ at $0.3 \mu \mathrm{m}$ and $100 \%$ for particles $>0.45 \mu \mathrm{m}$, according to ISO 21501-4). Finally, concentrations of $\mathrm{CO}_{2}$ and TVOCs (Total Volatile Organic Compound) were recorded by portable IAQ Tongdy sensors with a $\mathrm{CO}_{2}$ recording range from 0 to 
$2000 \mathrm{ppm}$ and accuracy of $\pm 40 \mathrm{ppm}$ at $25^{\circ} \mathrm{C}$ and TVOCs ranging from 1 to $30 \mathrm{ppm}$ with accuracy of $1 \mathrm{ppm})$. All parameters were measured on a $24 \mathrm{~h}$ basis at $15 \mathrm{~min}$ intervals. Quality assurance of the equipment used was performed in several occasions during the experimental campaign and all of the instruments were calibrated according to the manufacturers' standards.

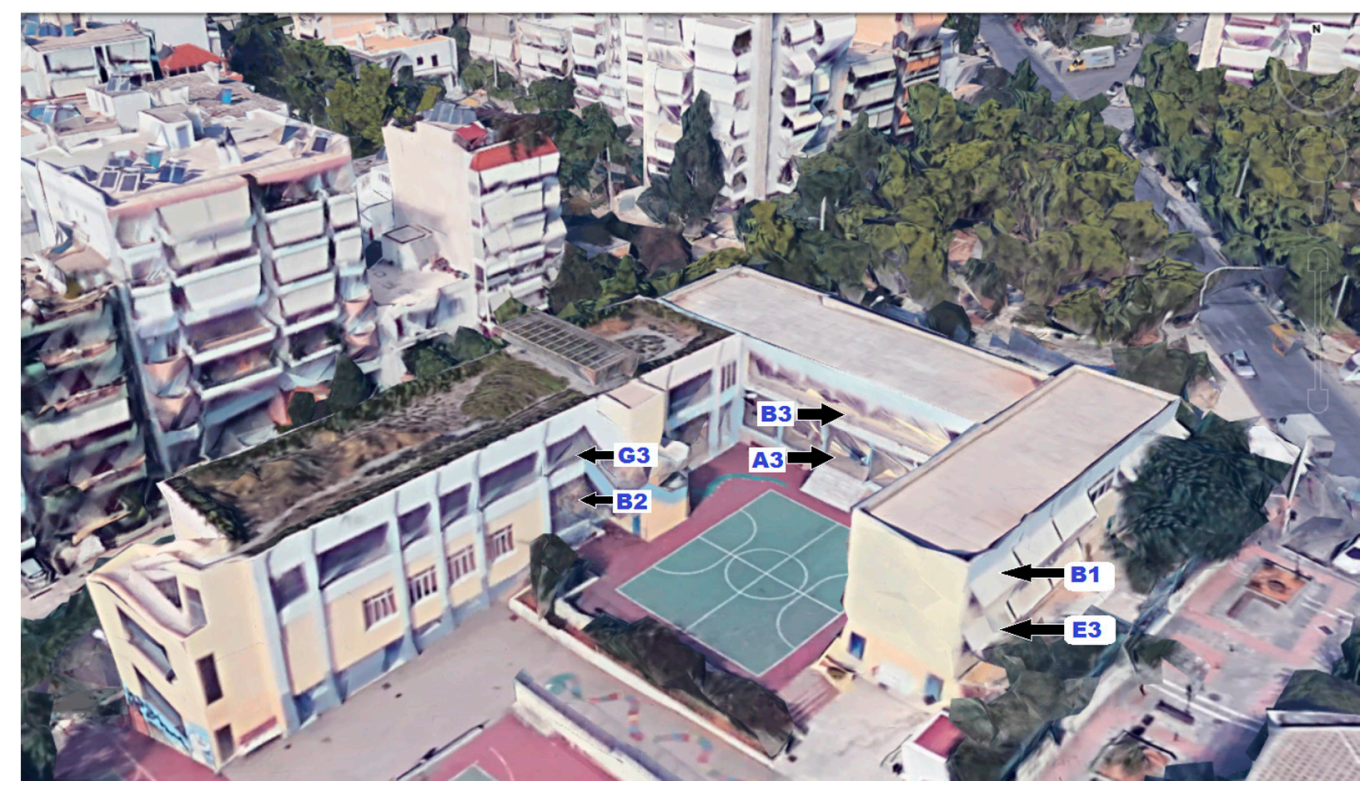

Figure 1. Aerial view of the 2nd primary school and the classrooms of interest in Nea Smyrni, Athens.

Concentration levels of $\mathrm{CO}_{2}$ depend mainly on the air exchange rates (AER) and total area of classrooms $\left(\mathrm{m}^{2}\right)$ as well as the number of students and the type of their activities within the school building. The selected method for calculating AER values in classrooms is based on the decay of $\mathrm{CO}_{2}$ over time [19-21]. According to this procedure a quantity of a tracer gas, usually $\mathrm{CO}_{2}$, which is produced by human exhalation into the examined room is mixing with fresh air and acquiring a uniform concentration within the space. After the end of classes when the $\mathrm{CO}_{2}$ concentrations present a maximum value, the rate of concentration reduction of the $\mathrm{CO}_{2}$ is measured [22]. The formula (2) of AER that has been proposed by [23] in general form and simplified by [24] for the case of $\mathrm{CO}_{2}$ is:

$$
\mathrm{AER}=-\frac{1}{\mathrm{t}-\mathrm{to}} \cdot \ln \left(\frac{\mathrm{C}(\mathrm{t})-\text { Cext }}{\mathrm{C} 0-\text { Cext }}\right)
$$

where $\mathrm{C} 0$ is the $\mathrm{CO}_{2}$ concentration at time $\mathrm{t}_{0}, \mathrm{C}(\mathrm{t})$ is the observed value of $\mathrm{CO}_{2}$ at time $\mathrm{t}$ and Cext is the outdoor concentration of $\mathrm{CO}_{2}$. In this case $\mathrm{t}_{0}$ represents the moment that $\mathrm{CO}_{2}$ was starting to decrease exponentially during time $t$.

All of the measurements were obtained from six classrooms, three at each floor and under the two different types of roof, enabling a direct comparison beneath the GRS and the reference cement roof. All the classrooms are naturally ventilated by window openings and were heated with oil combustion during the cold period of the year. For the same period, the windows were open only for a few minutes before and after class hours while during the lessons remained shut. On the contrary, amid the warm periods the frequent behavior was the windows to remain open when the school was occupied as the building does not have an air conditioning system. All of the classrooms retain a mosaic floor (a mix of cement with pieces of marble and granite) and blackboard with chalk. They are cleaned once a day after class hours. Table 1 demonstrates the characteristics of each classroom. A logbook of activities was kept by the researchers in order to include class hours, type of lessons, PTA (Parent-Teacher Association) meetings, and other school events. The recorded differences between groups of measurements were tested for significance using the non-parametric Mann Whitney-U test. 
All of the p-values found to be $<0.05$, allowing to reject the null hypothesis that there is no significant difference between the ranks of two grouping variables.

Table 1. Positioning, total area, volume, and occupancy for all examined classrooms.

\begin{tabular}{|c|c|c|}
\hline \multicolumn{3}{|c|}{ First floor } \\
\hline Classroom: G3 & Classroom: B3 & Classroom: B1 \\
\hline (under GRS) & (under cement roof) & (under cement roof) \\
\hline Area: $70 \mathrm{~m}^{2}$ & Area: $50 \mathrm{~m}^{2}$ & Area: $56 \mathrm{~m}^{2}$ \\
\hline Volume: $210 \mathrm{~m}^{3}$ & Volume: $150 \mathrm{~m}^{3}$ & Volume: $168 \mathrm{~m}^{3}$ \\
\hline Number of persons: 24 & Number of persons: 25 & Number of persons: 26 \\
\hline \multicolumn{3}{|c|}{ Ground floor } \\
\hline Classroom: B2 & Classroom: A3 & Classroom: E3 \\
\hline (under GRS) & (under cement roof) & (under cement roof) \\
\hline Area: $45 \mathrm{~m}^{2}$ & Area: $56 \mathrm{~m}^{2}$ & Area: $55 \mathrm{~m}^{2}$ \\
\hline Volume: $135 \mathrm{~m}^{3}$ & Volume: $168 \mathrm{~m}^{3}$ & Volume: $165 \mathrm{~m}^{3}$ \\
\hline Number of persons: 22 & Number of persons: 25 & Number of persons: 24 \\
\hline
\end{tabular}

\section{Results and Discussion}

\subsection{Thermal Effect of GRS}

The purpose of the campaign performed during June-July 2016 was to examine the temperature and relative humidity regimes of the classrooms when empty. Two classrooms adjacent to the two different types of roof were selected (G3 and B1) on the first floor having the same orientation. The results show that the roof type strongly affects the internal conditions of the classrooms investigated. Table 2 depicts the temperature, relative and absolute humidity for the two classrooms, and for the external environment of the school. The examined periods were separated to the cold period (October-March) and the warm (April-June) depending on when the heating system was operating. It should be noted that the two classrooms have a similar typology and they retain the same insulating materials for walls, windows, floors, and doors, except the roof type. Specifically, brick walls $\left(250 \mathrm{~mm}\right.$ ) with a coefficient of heat transmission (U value) equal to $2 \mathrm{~W} / \mathrm{m}^{2} \mathrm{~K}$, double glazed windows with distance between glasses $50 \mathrm{~mm}\left(\mathrm{U}=2.8 \mathrm{~W} / \mathrm{m}^{2} \mathrm{~K}\right)$, steel doors with no fiberglass insulation $\left(\mathrm{U}=1.20 \mathrm{~W} / \mathrm{m}^{2} \mathrm{~K}\right)$ and marble floor $(20 \mathrm{~mm}$ of marble and $200 \mathrm{~mm}$ of concrete $)\left(\mathrm{U}=2.2 \mathrm{~W} / \mathrm{m}^{2} \mathrm{~K}\right)$. The reference roof above classroom B1 consists of asphalt cover, perlite-bitumen bonded, concrete, and plaster, demonstrating a $\mathrm{U}$ value of $0.95 \mathrm{~W} / \mathrm{m}^{2} \mathrm{~K}$ while the addition of the lightweight GRS on classroom G3 with $150 \mathrm{~mm}$ of soil, jute felt, polyethylene (high density), asphalt cover, and perlite, led to a decrease of the heat transmission coefficient of the roof up to $0.18 \mathrm{~W} / \mathrm{m}^{2} \mathrm{~K}\left(\mathrm{U}=0.77 \mathrm{~W} / \mathrm{m}^{2} \mathrm{~K}\right)$. It is of importance to note what was also reported in the study of [25], where it was emphasized that GRS can generally improve energy efficiency of buildings both during the warm (cooling) and cold (heating) period of the year. This applies only for buildings with poor or moderate insulation, such as the examined case study. In new built structures however where the new insulating materials and regulations are used, the GRS will have a very slight effect on energy savings.

From June to July 2016 the average temperature (T) of the classroom under the GRS (G3) was $32.4{ }^{\circ} \mathrm{C}$, while the respective beneath the concrete roof (B1) was found to be $35.2{ }^{\circ} \mathrm{C}$. For the same period, the outdoor mean temperature on the GRS was found to be $30.1^{\circ} \mathrm{C}$ and on the cement roof $31.4^{\circ} \mathrm{C}$, respectively. From April to June 2017 average temperatures under the green and cement roof were $25.1^{\circ} \mathrm{C}$ and $26.4{ }^{\circ} \mathrm{C}$, and the external ones $21.9^{\circ} \mathrm{C}$ and $23.5^{\circ} \mathrm{C}$. Thus, the GRS leads to a decrease of air temperature by about $2.8^{\circ} \mathrm{C}$ for the first period and $1.3^{\circ} \mathrm{C}$ for the second one. On the contrary, for the same periods, the average absolute humidity $(\mathrm{AH})$ in both classrooms demonstrated no significant differences $\left(0.2 \mathrm{~g}_{\mathrm{H} 2 \mathrm{O}} \mathrm{m}^{-3}\right.$ and $0.4 \mathrm{~g}_{\mathrm{H} 2 \mathrm{O}} \mathrm{m}^{-3}$, respectively). During the cold period, the school is heated by boiler using heating oil that operates during class hours. The average internal temperature 
ranged from $19.7^{\circ} \mathrm{C}$ in the classroom under the GRS to $16.4{ }^{\circ} \mathrm{C}$ in the respective under the cement roof, while the mean absolute humidity was measured $8.2 \mathrm{~g}_{\mathrm{H} 2 \mathrm{O}} \mathrm{m}^{-3}$ under the GRS and $8.5 \mathrm{~g}_{\mathrm{H} 2 \mathrm{O}} \mathrm{m}^{-3}$ under the conventional one. Outdoor temperature presented mean values of $12.2^{\circ} \mathrm{C}$ on the GRS and $13.4{ }^{\circ} \mathrm{C}$ on the cement roof. An important observation is that the absolute humidity showed a relatively stable behavior for both classrooms during all of the experimental period. Since relative humidity (RH) strongly depends on the temperature and absolute pressure of a system of interest, it is concluded that even though the sense of humidity of the human body (RH) is different within the two microenvironments, the amount of water vapor in the air (AH) does not change significantly.

Table 2. Results of Temperature (T), relative Humidity ( $\mathrm{RH}$ ), and absolute humidity (AH) for classrooms of first floor under green and cement roof and for the external environment during different periods.

\begin{tabular}{|c|c|c|c|c|c|c|c|c|c|c|}
\hline \multirow[b]{2}{*}{$\begin{array}{c}\text { Experimental } \\
\text { Site }\end{array}$} & \multirow[b]{2}{*}{ Statistics } & \multicolumn{3}{|c|}{ June-July 2016} & \multicolumn{3}{|c|}{ October 2016-March 2017} & \multicolumn{3}{|c|}{ April-June 2017} \\
\hline & & $\mathrm{T}\left({ }^{\circ} \mathrm{C}\right)$ & $\begin{array}{l}\text { RH } \\
(\%)\end{array}$ & $\begin{array}{c}\mathrm{AH} \\
\left(\mathrm{g}_{\mathrm{H} 2 \mathrm{O}} \mathrm{m}^{-3}\right)\end{array}$ & $\begin{array}{c}\mathrm{T} \\
\left({ }^{\circ} \mathrm{C}\right) \\
\end{array}$ & $\begin{array}{l}\text { RH } \\
(\%)\end{array}$ & $\begin{array}{c}\mathrm{AH} \\
\left(\mathrm{g}_{\mathrm{H} 2 \mathrm{O}} \mathrm{m}^{-3}\right)\end{array}$ & $\mathrm{T}\left({ }^{\circ} \mathrm{C}\right)$ & $\begin{array}{l}\text { RH } \\
(\%)\end{array}$ & $\begin{array}{c}\mathrm{AH} \\
\left(\mathrm{g}_{\mathrm{H} 2 \mathrm{O}} \mathrm{m}^{-3}\right)\end{array}$ \\
\hline \multirow{4}{*}{$\begin{array}{c}\text { 1st floor } \\
\text { classroom } \\
\text { under GRS (G3) }\end{array}$} & average & 32.4 & 41.0 & 14.2 & 19.7 & 47.4 & 8.2 & 25.1 & 46.7 & 11.0 \\
\hline & $\begin{array}{c}\text { St. } \\
\text { deviation }\end{array}$ & 1.1 & 2.4 & 1.1 & 3.1 & 7.9 & 2.2 & 2.4 & 5.4 & 2.3 \\
\hline & minimum & 29.1 & 29.5 & 10.6 & 10.8 & 26.6 & 3.7 & 20.8 & 28.0 & 6.1 \\
\hline & maximum & 33.8 & 46.1 & 16.4 & 27.7 & 74.1 & 15.8 & 30.6 & 61.1 & 16.2 \\
\hline \multirow{4}{*}{$\begin{array}{c}\text { 1st floor } \\
\text { classroom } \\
\text { under cement } \\
\text { roof (B1) }\end{array}$} & average & 35.2 & 35.1 & 14.0 & 16.4 & 59.2 & 8.5 & 26.4 & 45.5 & 11.4 \\
\hline & $\begin{array}{c}\text { St. } \\
\text { deviation }\end{array}$ & 1.2 & 2.9 & 1.0 & 4.2 & 6.4 & 2.1 & 3.8 & 4.6 & 2.2 \\
\hline & minimum & 30.9 & 27.7 & 10.7 & 6.0 & 35.4 & 3.8 & 19.1 & 30.1 & 6.6 \\
\hline & maximum & 37.8 & 40.5 & 16.0 & 26.2 & 78.0 & 17.0 & 37.1 & 57.5 & 17.5 \\
\hline \multirow{4}{*}{ Outdoor (GRS) } & average & 30.1 & 53.7 & 15.8 & 12.2 & 67.8 & 7.6 & 21.9 & 57.0 & 11.1 \\
\hline & $\begin{array}{c}\text { St. } \\
\text { deviation }\end{array}$ & 4.7 & 15.5 & 2.4 & 5.9 & 23.6 & 3.5 & 6.0 & 17.1 & 3.7 \\
\hline & minimum & 19.8 & 0.0 & 0.0 & -2.9 & 0.0 & 0.0 & 6.5 & 0.0 & 0.0 \\
\hline & maximum & 43.3 & 100.0 & 23.8 & 29.9 & 100.0 & 21.8 & 37.0 & 100.0 & 24.6 \\
\hline \multirow{4}{*}{$\begin{array}{c}\text { Outdoor } \\
\text { (cement roof) }\end{array}$} & average & 31.4 & 47.8 & 15.1 & 13.4 & 66.6 & 7.8 & 23.5 & 51.0 & 10.7 \\
\hline & $\begin{array}{c}\text { St. } \\
\text { deviation }\end{array}$ & 4.2 & 14.5 & 2.2 & 5.5 & 16.2 & 2.5 & 5.5 & 16.1 & 3.3 \\
\hline & minimum & 22.0 & 0.0 & 0.0 & -1.4 & 17.2 & 2.6 & 10.3 & 16.0 & 3.0 \\
\hline & maximum & 41.0 & 100.0 & 25.3 & 29.0 & 100.0 & 17.1 & 38.8 & 100.0 & 26.2 \\
\hline
\end{tabular}

In Figure 2a one may observe that during the cold period, the temperature in G3 (under GRS) lies mostly within the recommended range $\left(20-23^{\circ} \mathrm{C}\right)$, thus creating a more comfortable environment. Moreover, in Figure $2 \mathrm{~b}$ it is shown that amid the two warm periods, relative humidity in both of the classrooms is within the recommended range. During the cold months, mostly in G3, the relative humidity limits are not overpassed (30-60\% annually). The limits of both parameters are based on the standard of [26], reported in [27]. From the same figures, the percentage of time where temperature and relative humidity values were outside the recommended limit range was calculated in order to demonstrate that GRS provide better comfort parameters during most of the time. Indicatively, during warm periods, $80.6 \%$ of temperature measurements overpassed the limit range in the classroom under GRS (G3) and $86.2 \%$ in the respective under cement roof (B1). For the cold period, $65.1 \%$ of temperature recordings were outside the limit range in G3, while $81.8 \%$ within B1. Concerning relative humidity, only $3.3 \%$ of measurements found out of the limit area in the classroom under GRS for all of the experimental period, while $27.1 \%$ in the respective classroom under cement roof. Figure $2 \mathrm{c}$ depicts that the behavior of absolute humidity shows similar fluctuations with temperature (Figure 2a) for each season, especially during class hours (opening of windows), but without significant differences between the two classrooms. 


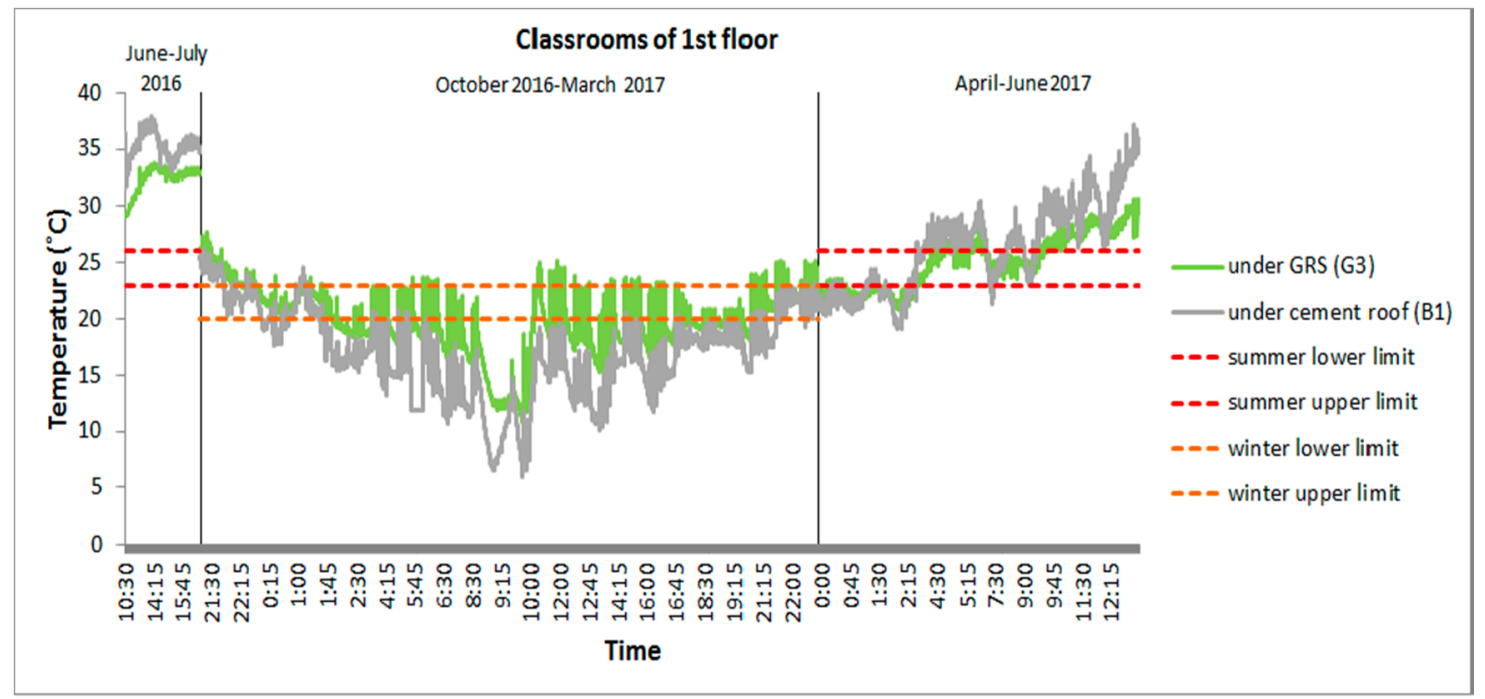

(a)

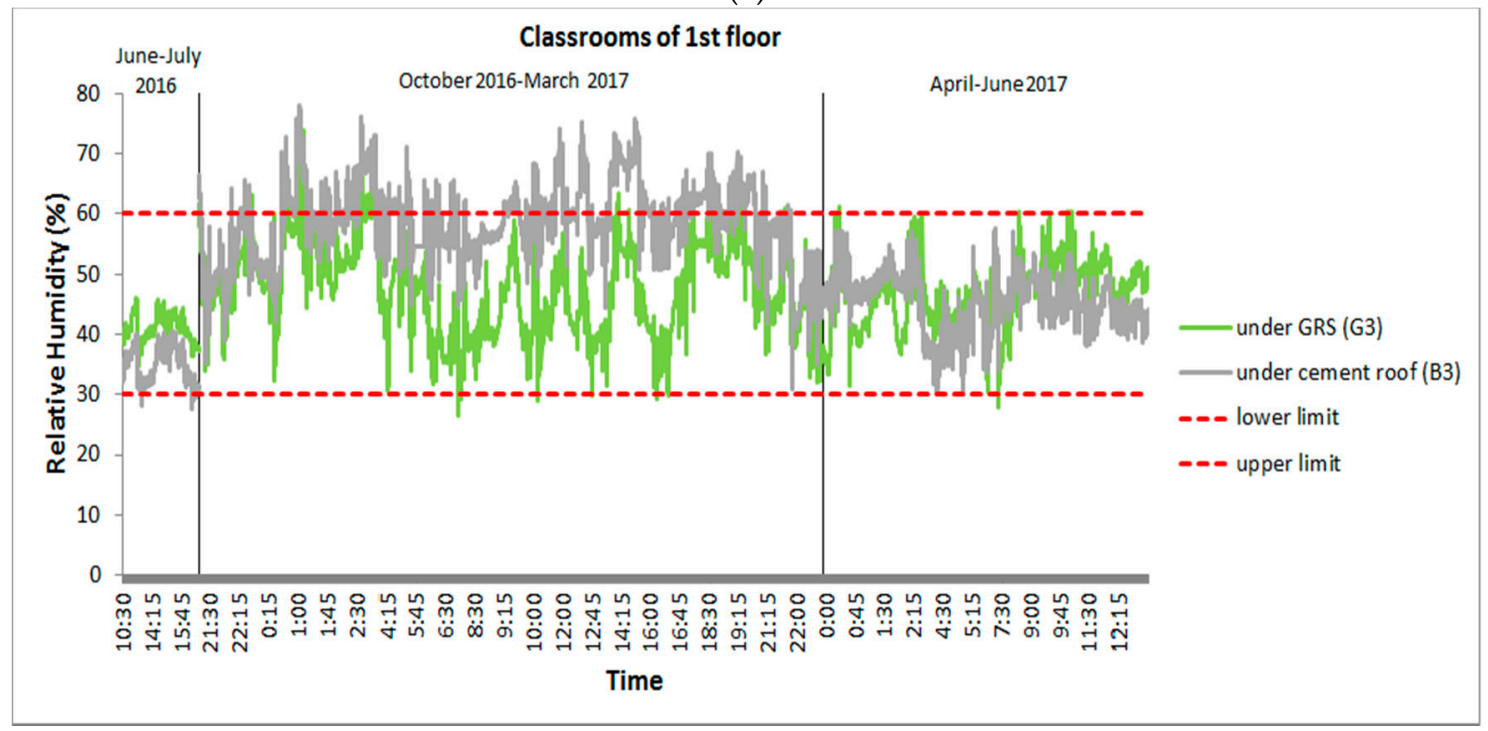

(b)

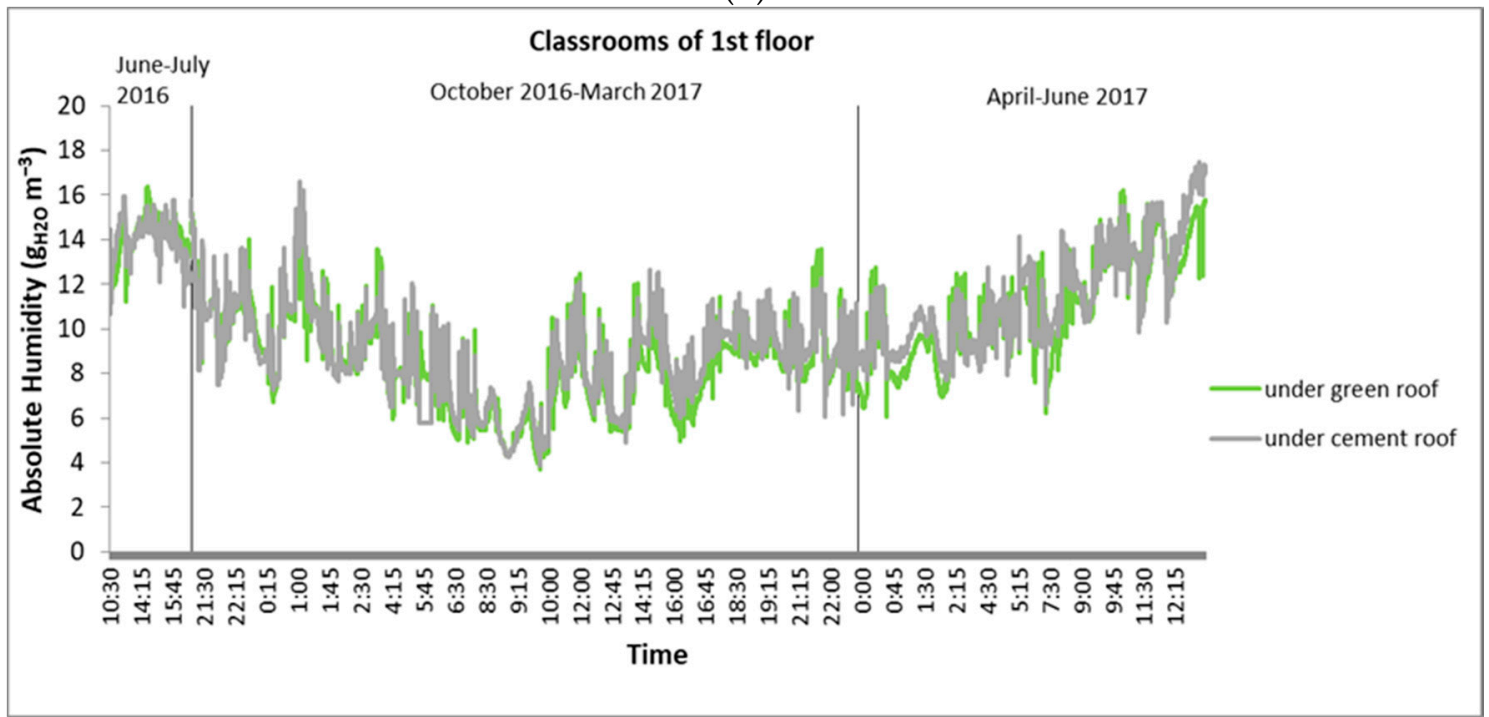

(c)

Figure 2. Time series of (a) Temperature; (b) Relative Humidity; and, (c) Absolute Humidity for the two classrooms under green and cement roof. 


\subsection{Air Exchange Rates}

In this section, the results of AER for the 6 examined classrooms (demonstrated in Table 1) are presented. The recording of $\mathrm{CO}_{2}$ in classrooms lasted for 12 hours per day (from 18.00 to 6.00 LST) when empty (no presence of auxiliary personnel). During this period, doors and windows (double-glazed aluminum frame) in all of the classrooms remained shut. Figure 3 shows a typical 24-hour distribution of $\mathrm{CO}_{2}$ during an experimental day in classroom $\mathrm{G} 3$, where the exponential decay period is obvious.

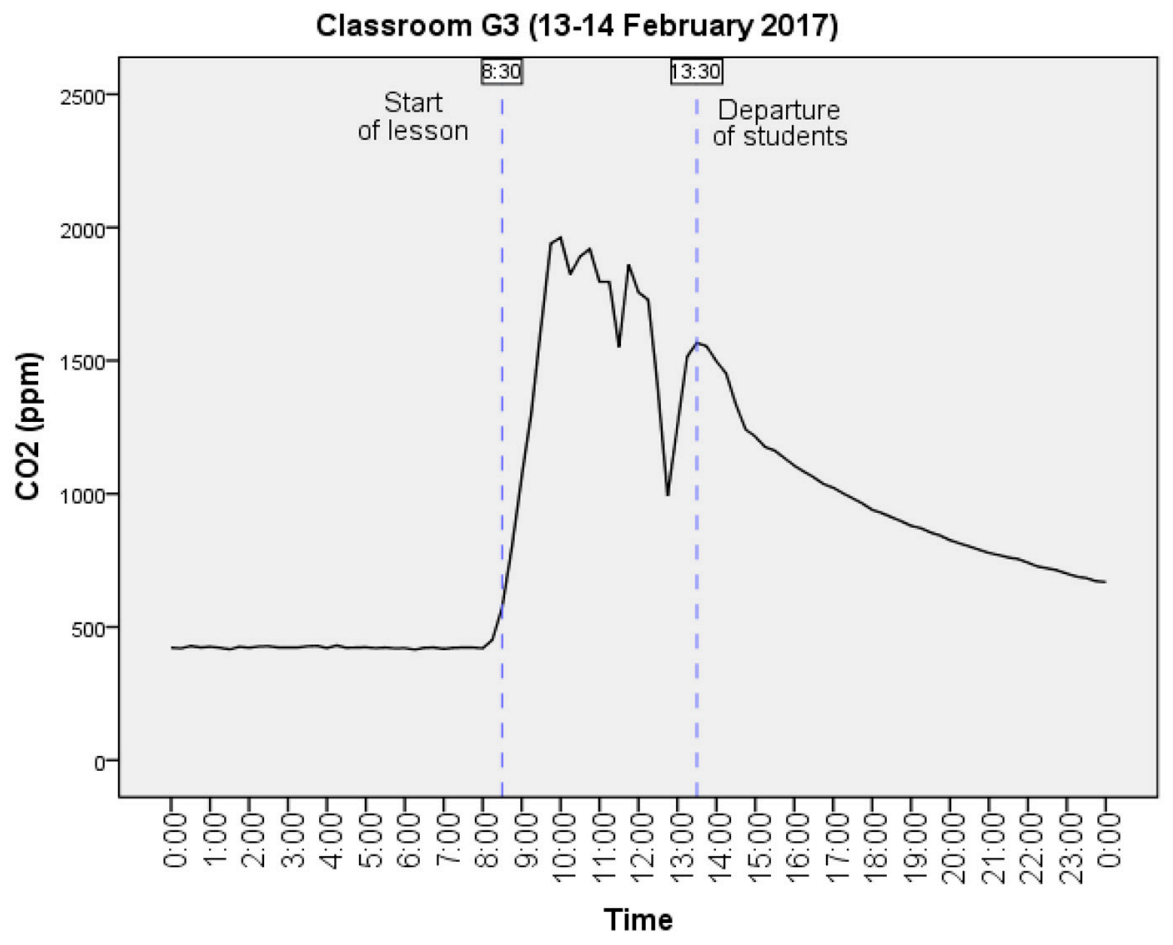

Figure 3. A daily distribution of $\mathrm{CO}_{2}$ concentration in $\mathrm{G} 3$ classroom.

The AER of each classroom was estimated by the slope of the logarithm of $\mathrm{CO}_{2}$ concentrations against time for different days based on equation (2). Each day was selected on the basis of no human presence within the classrooms. In Figure 4, the case of classroom G3 is presented, where measurements took place from 13 to 14 February 2017. During this period, all of the windows and doors remained shut. The natural logarithm $(\mathrm{ln})$ of the difference between the internal concentration of $\mathrm{CO}_{2}$ at every time interval $\mathrm{t}, \mathrm{C}(\mathrm{t})$, and the respective external (Cext) is illustrated graphically. After a linear regression, the calculated slope represents the value of AER. The high value of the coefficient of determination $\left(R^{2}=0.9852\right)$ indicates relatively stable conditions. Table 3 depicts that for all of the classrooms, the results demonstrated very low values of AER, from $0.04 \mathrm{~h}^{-1}$ in classroom B3 to $0.29 \mathrm{~h}^{-1}$ in $\mathrm{B} 2$, which may be attributed to the newly installed windows that provide better isolation from the outdoor environment. However, most classrooms present high variability in AER values for all the selected days with A3 and B3 to have the most stable behavior, mostly because of their positioning inside the building (protected from the wind effect). The research of [28] reports that $0.5 \mathrm{~h}^{-1}$ is frequently referred in national standards and regulations in Europe and is considered as a threshold of adequate infiltration rate. However, it must not be linked with health symptoms. It is concluded that AER in the natural ventilated classrooms of the examined building demonstrate very low values. Moreover, it should be noted that since the AER is calculated while the classrooms remain empty and shut, any difference between warm and cold periods are very small (as the conditions remain almost the same). 


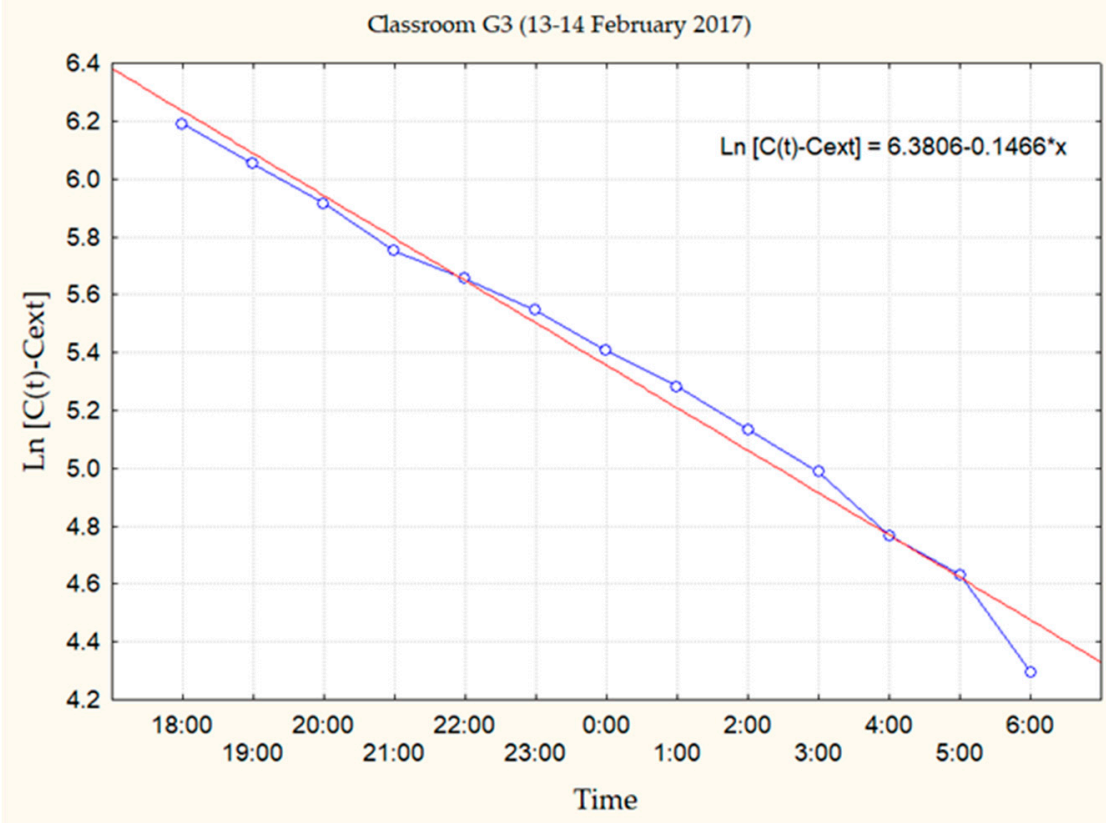

Figure 4. A $12 \mathrm{~h}$ decay period and linear regression of $\mathrm{CO}_{2}$ in classroom $\mathrm{G} 3$ for a specific day.

Table 3. Air Exchange Rates (AER) results in examined classrooms during different experimental days.

\begin{tabular}{ccccccc}
\hline \multicolumn{7}{c}{ AER [ $\mathbf{h}^{-\mathbf{1}}$ ] } \\
\hline Days & G3 & B2 & B3 & A3 & B1 & E3 \\
$31 / 1-1 / 2$ & 0.13 & - & - & - & 0.07 & 0.10 \\
$1 / 2-2 / 2$ & 0.09 & 0.15 & - & - & 0.06 & - \\
$2 / 2-3 / 2$ & 0.07 & - & 0.02 & - & & - \\
$6 / 2-7 / 2$ & 0.21 & - & - & - & 0.09 & 0.15 \\
$13 / 2-14 / 2$ & 0.15 & - & 0.06 & 0.06 & 0.07 & 0.16 \\
$14 / 2-15 / 2$ & 0.10 & - & 0.04 & - & 0.03 & - \\
$15 / 2-16 / 2$ & 0.08 & - & 0.03 & - & - & - \\
$16 / 2-17 / 2$ & 0.11 & 0.31 & - & - & 0.06 & 0.10 \\
$17 / 2-18 / 2$ & 0.15 & 0.60 & 0.04 & - & 0.09 & - \\
$23 / 2-24 / 2$ & 0.08 & - & 0.04 & - & 0.08 & 0.10 \\
$24 / 2-25 / 2$ & - & - & 0.03 & - & 0.04 & - \\
$28 / 2-1 / 3$ & - & - & - & - & 0.03 & 0.09 \\
$1 / 3-2 / 3$ & - & - & 0.04 & - & 0.06 & 0.12 \\
$2 / 3-3 / 3$ & 0.07 & - & 0.03 & - & - & - \\
$7 / 3-8 / 3$ & 0.14 & - & 0.05 & - & - & 0.14 \\
$8 / 3-9 / 3$ & 0.09 & 0.18 & 0.04 & - & 0.04 & - \\
$27 / 3-28 / 3$ & 0.12 & - & - & 0.05 & 0.06 & 0.15 \\
$6 / 4-7 / 4$ & 0.08 & - & - & 0.05 & - & 0.08 \\
$5 / 5-6 / 5$ & - & 0.20 & 0.04 & 0.05 & 0.06 & 0.17 \\
$9 / 5-10 / 5$ & 0.09 & - & - & 0.05 & - & 0.32 \\
$17 / 5-18 / 5$ & 0.10 & - & 0.08 & 0.06 & - & - \\
Average & 0.11 & 0.29 & 0.04 & 0.05 & 0.06 & 0.14 \\
\hline & & & & & & \\
\hline
\end{tabular}

\subsection{Air Quality}

\subsubsection{Particulate Matters}

Previous studies have provided us with an abundance of data concerning PM concentrations. In [29], where twenty seven schools were investigated, it is showcased that there was no established 
linear correlation between indoor and outdoor levels for $\mathrm{PM}_{2.5}$ mass concentrations, and the indoor-outdoor ratios exceeded unity, due to dust resuspension. $\mathrm{PM}_{2.5}$ found inside the classrooms occurred with a different elemental composition to the respective of outdoors. Additionally, in [30], it is shown that apart from one out of eight schools, I/O ratios varied in the range from 0.03 to 1.79. The schoolroom occupancy influenced the indoor concentration through particle resuspension and the ratio was found to decrease with increasing particle size. Finally, in [31] one may see that average values of $\mathrm{I} / \mathrm{O}$ ratios range from 1.02 to 1.08 for $\mathrm{PM}_{2.5}$.

Concentrations of suspended particles were measured into two classrooms of the first floor under GRS and cement roof (G3 and B1), and simultaneously on the external environment of the building. The results indicate relatively low PM concentrations with respect to [32] for both classrooms. The position of each classroom (beneath green or concrete roof system) did not seem to affect the levels of particulate matter. Indicatively, the average concentrations of $\mathrm{PM}_{1}, \mathrm{PM}_{2.5}$, and $\mathrm{PM}_{10}$ were $0.79,3.39$, and $27.80 \mu \mathrm{g} \mathrm{m}^{-3}$ for the classroom under the GRS and $0.82,2.83$, and $28.34 \mu \mathrm{g} \mathrm{m}^{-3}$ for the respective under the reference cement roof. However, temporal variation seems to play an important role to the particulate distribution [33]. The mean in/out (I/O) ratio of the three types of airborne particles was calculated with and without the presence of pupils. $\mathrm{PM}_{10}$ during class hours (for a selected period from January to April) was found to be equal to 3.05. On the contrary, in the summer when there is no human presence in the school, the $\mathrm{PM}_{10} \mathrm{I} / \mathrm{O}$ ratio was 0.60 in June and 0.46 in July. Thus, it is concluded that indoor $\mathrm{PM}_{10}$ concentrations are presented in higher levels than those of outdoors, when the school is operating. Activities of pupils, causing the resuspension of large particles are mainly responsible for the higher PM exposure in classrooms. The above statement is in agreement with previous published researches by [34] and [35]. For the same months, I/O ratio of $\mathrm{PM}_{2.5}$ and $\mathrm{PM}_{1}$ remained $<1$, which demonstrates the significant influence of external sources of emission. Based on school's orientation and wind direction, potential sources could be the traffic from the city's center (NNW) and emissions from the ships of the nearby port (SW) (Figure 5). Table 4 summarizes the results of particulate matters concerning class hours.

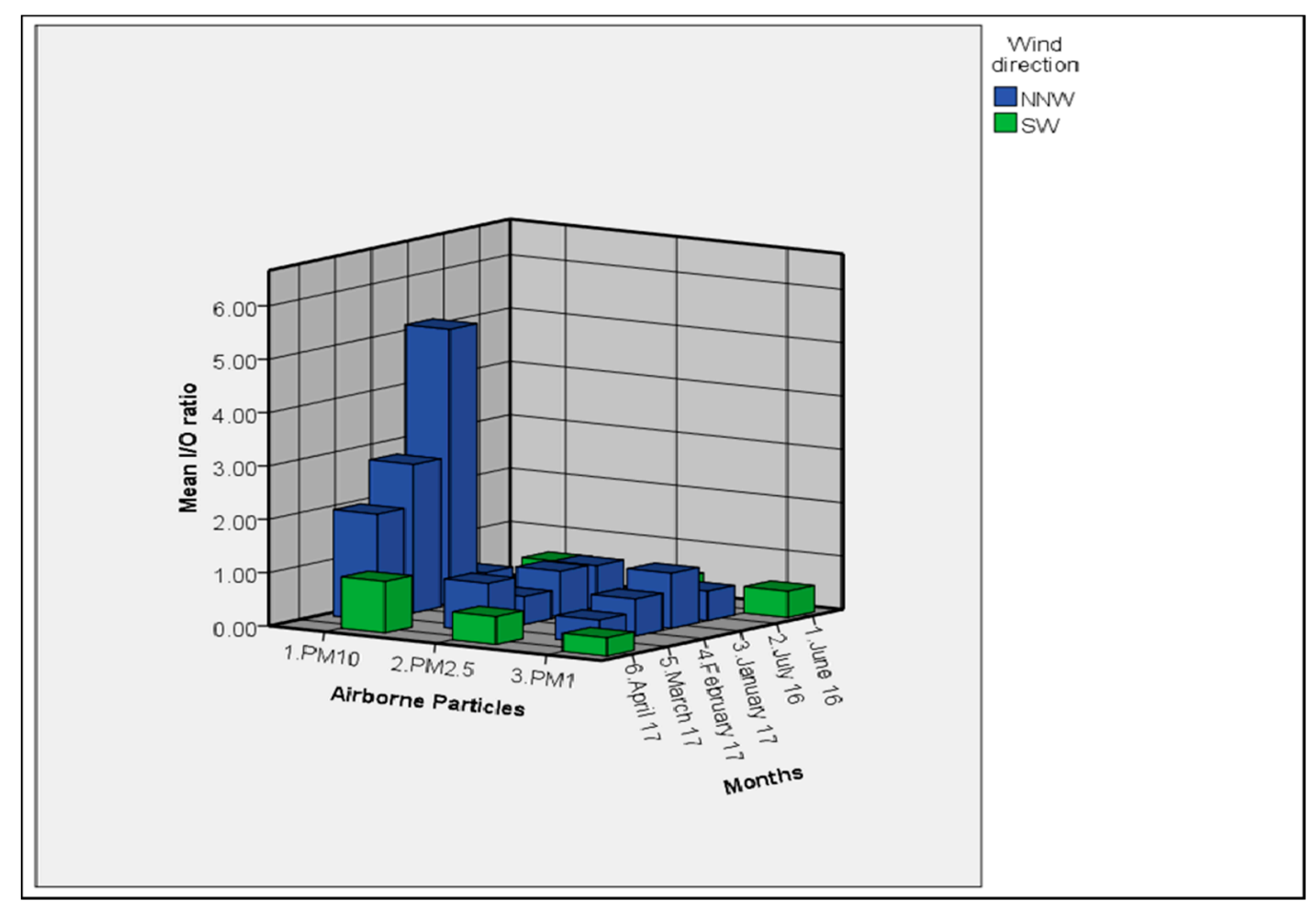

Figure 5. Indoor to outdoor $(\mathrm{I} / \mathrm{O})$ ratio for all the measured airborne particles during different months under the influence of wind direction. 
Table 4. Descriptive statistics for concentrations and indoor to outdoor (I/O) ratio of particulate matters in classroom G3 (under GRS) and B1 (under cement roof) from January to April 2017.

\begin{tabular}{cccccccccc}
\hline \multicolumn{1}{c}{ January-April 2017 (class hours) } \\
\hline Statistics & $\begin{array}{c}\mathrm{PM}_{1} \\
\left(\mu \mathrm{g} \mathrm{m}^{-3}\right)\end{array}$ & $\begin{array}{c}\mathrm{PM}_{2.5} \\
\left(\mu \mathrm{g} \mathrm{m}^{-3}\right)\end{array}$ & $\begin{array}{c}\mathrm{PM}_{10} \\
\left(\mu \mathrm{g} \mathrm{m}^{-3}\right)\end{array}$ & $\begin{array}{c}\mathrm{PM}_{1} \\
\left(\mu \mathrm{g} \mathrm{m}^{-3}\right)\end{array}$ & $\begin{array}{c}\mathrm{PM}_{2.5} \\
\left(\mu \mathrm{g} \mathrm{m}^{-3}\right)\end{array}$ & $\begin{array}{c}\mathrm{PM}_{10} \\
\left(\mu \mathrm{g} \mathrm{m}^{-3}\right)\end{array}$ & $\begin{array}{c}\mathrm{PM}_{1} \\
\mathrm{I} / \mathrm{O}\end{array}$ & $\begin{array}{c}\mathrm{PM}_{2.5} \\
\mathrm{I} / \mathrm{O}\end{array}$ & $\begin{array}{c}\mathrm{PM}_{10} \\
\mathrm{I} / \mathrm{O}\end{array}$ \\
$\begin{array}{c}\text { Mean } \\
\text { Median }\end{array}$ & 0.79 & $\mathrm{G} 3$ & $\mathrm{G} 3$ & $\mathrm{~B} 1$ & $\mathrm{~B} 1$ & $\mathrm{G} 3 \& \mathrm{~B} 1$ & $\mathrm{G} 3 \& \mathrm{~B} 1$ \\
$\quad$ Std. & 0.70 & 3.39 & 27.80 & 0.82 & 2.83 & 28.34 & 0.67 & 0.72 & 3.05 \\
Deviation & 0.39 & 0.94 & 25.28 & 0.61 & 2.65 & 23.62 & 0.45 & 0.57 & 2.09 \\
Minimum & 0.16 & 1.72 & 20.00 & 0.64 & 0.95 & 26.09 & 0.56 & 0.71 & 3.19 \\
Maximum & 1.90 & 5.26 & 71.62 & 0.15 & 1.72 & 2.64 & 0.11 & 0.14 & 0.21 \\
\hline
\end{tabular}

\subsubsection{Carbon Dioxide and Total Volatile Organic Compounds}

An additional parameter to characterize indoor air quality is the level of $\mathrm{CO}_{2}$. According to [36], the maximum occupancy in classroom environments recommended by [37] is 50 persons per $100 \mathrm{~m}^{2}$. Moreover, [38] mention that a steady state indoor $\mathrm{CO}_{2}$ concentration of $1000 \mathrm{ppm}$ has been used as an informal dividing line between adequate and inadequate ventilation [39]. Within the classrooms of the experimental site, mean $\mathrm{CO}_{2}$ levels range from $469 \mathrm{ppm}$ to $779 \mathrm{ppm}$, with a maximum value of 1999 ppm in classroom B3. The results demonstrate strong variation for each classroom, and as expected, tend to increase during class hours and to decrease during breaks and weekends.

From Figure 6, one may observe that classroom B3, on the first floor, showed the highest average concentrations of total TVOCs (13.33 ppm), while the lowest were presented in classroom B2 (6.63 ppm). It is noted that $\mathrm{A} 3$ is the only classroom that does not illustrate instant minimum or maximum values (outliers), demonstrating a relatively stable behavior even though it depicts a large range of concentrations. Within the rest of the classrooms, some outliers are presented mainly due to internal activities (such as painting lessons). Moreover, the two classrooms under the GRS (G3 and B2) are appearing to have the lowest concentrations of TVOCs as they retain less furnishing. Generally, the concentration levels of TVOCs for all classrooms remained relatively low, under the respective limit of tolerance (15 to $20 \mathrm{ppm}$ ), as referred in [40]. For a period of six months, the I/O ratio for most of the classrooms was found to be higher than 1 (with some exceptions for G3, B2 and A3), indicating that TVOCs indoor concentrations exceeded outdoor levels and appeared to dominate personal exposures [41]. Specifically, for the case of classroom A3, during May, the I/O ratio appeared to reach a value of 11.83 demonstrating strong internal sources of TVOCs emission. They mainly originate from classroom activities, cleaning products, room fresheners, wood, and furnishing [42,43]. Figure 7, illustrates the values of I/O TVOCs ratio for the selected experimental points. An overview of $\mathrm{CO}_{2}$ and TVOCs concentration results is summarized in Table 5. 


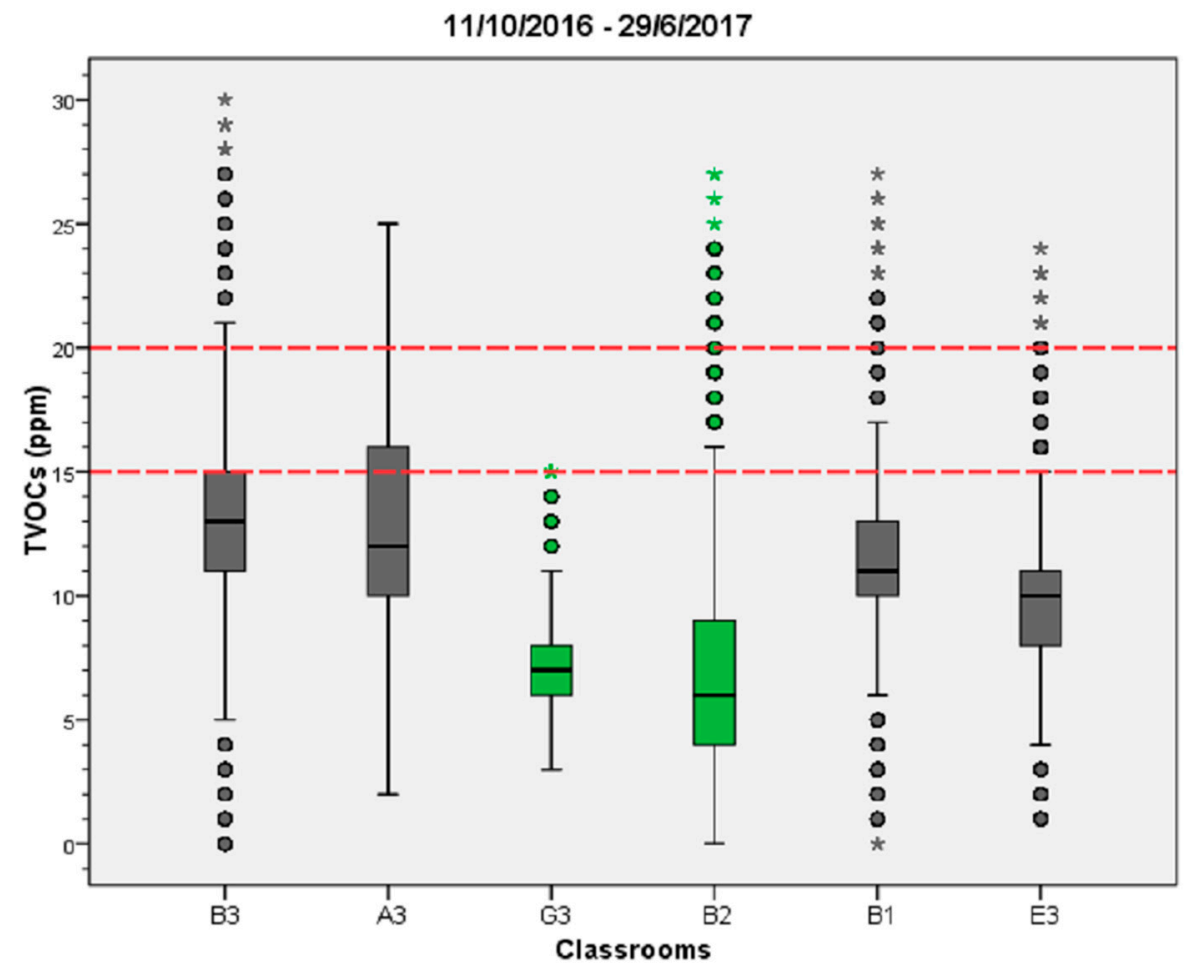

Figure 6. Boxplots of TVOCs concentrations in classrooms for all experimental period. The green color represents classrooms under the green roof system (GRS) and the grey the respective under cement roof.

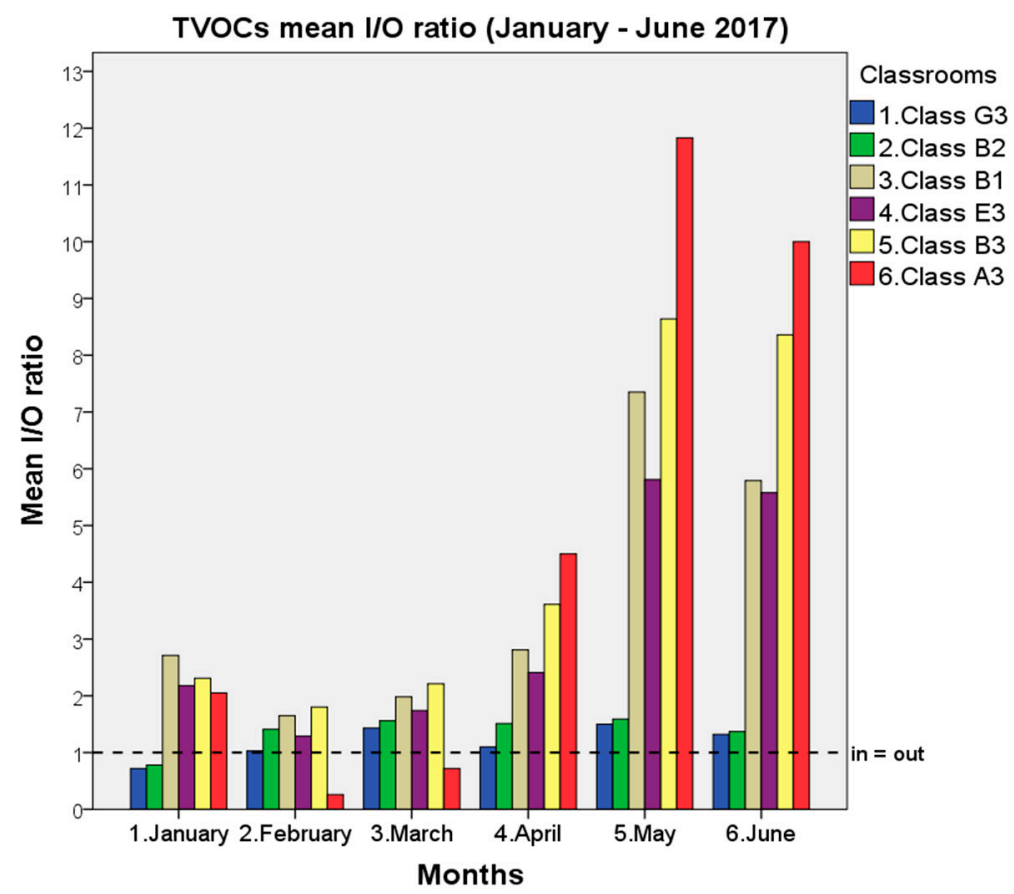

Figure 7. TVOCs indoor to outdoor (I/O) ratio for all classrooms, from January to June 2017. 
Table 5. Descriptive statistics of $\mathrm{CO}_{2}$ and TVOCs concentrations in all of the classrooms for all experimental period.

\begin{tabular}{ccccccccccccc}
\hline \multicolumn{1}{c}{ B3 } & \multicolumn{2}{c}{ A3 } & \multicolumn{2}{c}{ G3 } & \multicolumn{2}{c}{ B2 } & \multicolumn{2}{c}{ B1 } & \multicolumn{2}{c}{ E3 } \\
\hline [=] ppm & $\mathbf{C O}_{2}$ & TVOCs & $\mathbf{C O}_{2}$ & TVOCs & $\mathbf{C O}_{2}$ & TVOCs & $\mathbf{C O}_{2}$ & TVOCs & $\mathbf{C O}_{2}$ & TVOCs & CO & TVOCs \\
\hline Average & 779 & 13.33 & 584 & 12.62 & 713 & 7.38 & 469 & 6.63 & 683 & 11.81 & 515 & 10.06 \\
St. Dev. & 441 & 3.44 & 198 & 3.97 & 379 & 1.90 & 73 & 4.11 & 367 & 3.58 & 146 & 2.86 \\
25\% & 447 & 11.00 & 445 & 10.00 & 435 & 6.00 & 427 & 4.00 & 439 & 10.00 & 428 & 8.00 \\
$50 \%$ (median) & 562 & 13.00 & 507 & 12.00 & 538 & 7.00 & 442 & 6.00 & 513 & 11.00 & 455 & 10.00 \\
75\% & 1021 & 15.00 & 664 & 16.00 & 876 & 8.00 & 475 & 9.00 & 782 & 13.00 & 540 & 11.00 \\
Minimum & 384 & $<1.00$ & 372 & 2.00 & 394 & 3.00 & 396 & $<1.00$ & 360 & $<1.00$ & 394 & 1.00 \\
Maximum & 1999 & 30.00 & 1481 & 25.00 & 1996 & 15.00 & 922 & 27.00 & 1997 & 27.00 & 1291 & 24.00 \\
\hline
\end{tabular}

\section{Conclusions}

The results of a ten month experimental campaign in a Greek primary school are presented in this paper. Part of the building has an installed GRS system, while the other part is made of cement. The study was performed to identify differences between classroom microenvironments in terms of thermal conditions, air exchange rates, and air quality under the GRS and cement roof. The effect of the GRS on the top floor classroom, which is located underneath, is obvious in terms of thermal conditions, as compared to the classroom under the cement roof. Indoor air quality in classrooms, seem to be unaffected by the type of roof. The temporal variation is an additional parameter that strongly influences the results.

More specifically, the GRS has a positive thermal effect on the classroom directly underneath as compared to the respective classroom under the cement roof. Internal temperature levels in the classroom underneath the GRS were lower during the warm period (but still elevated compared to the respective limits) and higher during the cold months (within the recommended limits). The relative humidity in the same classroom was higher during the warm period and slightly lower for the cold one, but overall into the proposed limit range. Absolute humidity did not demonstrate significant fluctuations in both classrooms for all of the experimental period.

The AER of each classroom demonstrated very low values, which may due to the new double glazed aluminum frames of the classrooms, as the school is naturally ventilated. However, there is a large range of AER values within the classrooms because of their different positions and orientations in the building that result to a variety of influences by external factors, such as the wind. This is further supported by the $\mathrm{CO}_{2}$ and TVOCs concentrations in the classrooms, which during lessons reached high values since both pollutants had strong indoor sources.

Regarding particulate levels in the classrooms, the two types of roof did not seem to affect the air quality. In fact, very low concentrations of $\mathrm{PM}_{1}$ and $\mathrm{PM}_{2.5}$ were recorded indicating the absence of indoor sources, while the levels of $\mathrm{PM}_{10}$ remained generally higher which may be attributed to indoor activities of students, materials, and resuspension.

Overall, the GRS of the specific school building demonstrates a positive influence on the indoor thermal comfort conditions while the air quality regime is not significantly affected and relies heavily on good ventilation practices.

Acknowledgments: The authors would like to thank the Ministry of Education, Research and Religious Affairs of Greece for licensing the experiment and moreover the Direction of the 2nd primary school of Nea Smyrni for their cooperation and contribution to the measurements.

Author Contributions: All authors equally contributed to the paper.

Conflicts of Interest: The authors declare no conflict of interest.

\section{References}

1. Kolokotsa, D.; Diakaki, C.; Papantoniou, S.; Vlissidis, A. Numerical and experimental analysis of cool roofs application on a laboratory building in Iraklion, Crete Greece. Energy Build. 2012, 55, 85-93. [CrossRef] 
2. Yang, J.; Yu, Q.; Gong, P. Quantifying air pollution removal by green roofs in Chicago. Atmos. Environ. 2008, 42, 7266-7273. [CrossRef]

3. Kim, J.; Hong, T.; Koo, C. Economic and environmental evaluation model for selecting the optimum design of green roof systems in elementary schools. Environ. Sci. Technol. 2012, 46, 8475-8483. [CrossRef] [PubMed]

4. Hong, T.; Kim, J.; Koo, C. LCC and LCCO2 analysis of green roofs in elementary schools with energy saving measures. Energy Build. 2012, 45, 229-239. [CrossRef]

5. Badiee, A. The Impact of Roofing Material on Building Energy Performance. Masters of Science Thesis, University of Alabama, Birmingham, AL, USA, 2015.

6. Perini, K. Retrofitting with vegetation recent building heritage applying a design tool—The case study of a school building. Front Archit. Res. 2013, 2, 267-277. [CrossRef]

7. Ascione, F.; Bianco, N.; De Masi, R.F.; De Rossi, F.; Vanoli, G.P. Mitigating the cooling need and improvement of indoor conditions in Mediterranean educational buildings, by means of green roofs. Results of a case study. J. Phys.: Conference Series 2015, 655, 012027. [CrossRef]

8. Daisey, J.M.; Angell, W.J.; Apte, M.G. Indoor air quality, ventilation and health symptoms in schools: An analysis of existing information. Indoor Air 2003, 13, 53-64. [CrossRef] [PubMed]

9. Godwin, C.; Batterman, S. Indoor air quality in Michigan schools. Indoor Air 2007, 17, 109-121. [CrossRef] [PubMed]

10. Almeida, S.M.; Canha, N.; Silva, A.; Freitas, M.D.; Pegas, P.; Alves, C.; Evtyugina, M.; Pio, C.A. Children exposure to atmospheric particles in indoor of Lisbon primary schools. Atmos. Environ. 2011, 45, 7594-7599. [CrossRef]

11. Fuoco, F.; Stabile, L.; Buonanno, G.; Trassiera, C.V.; Massimo, A.; Russi, A.; Mazaheri, M.; Morawska, L.; Andrade, A. Indoor air quality in naturally ventilated Italian classrooms. Atmosphere 2015, 6, 1652-1675. [CrossRef]

12. Saraga, D.E.; Maggos, T.; Helmis, C.G.; Michopoulos, J.; Bartzis, J.G.; Vasilakos, C. PM 1 and PM 2.5 Ionic Composition and VOCs Measurements in Two Typical Apartments in Athens, Greece: Investigation of Smoking Contribution to Indoor Air Concentrations. Environ. Monit. Assess. 2010, 67, 321-331. [CrossRef] [PubMed]

13. Rakotondramiarana, H.; Ranaivoarisoa, T.; Morau, D. Dynamic Simulation of the Green Roofs Impact on Building Energy Performance, Case Study of Antananarivo, Madagascar. Buildings 2015, 5, 497-520. [CrossRef]

14. Jaffal, I.; Ouldboukhitine, S.; Belarbi, R. A comprehensive study of the impact of green roofs on building energy performance. Renew. Energy 2012, 43, 157-164. [CrossRef]

15. Moghbel, M.; Salim, R. Environmental benefits of green roofs on microclimate of Tehran with specific focus on air temperature, humidity and $\mathrm{CO}_{2}$ content. Urban Climate 2017, 20, 46-58. [CrossRef]

16. Huang, K.T.; Huang, W.P.; Lin, T.P.; Hwang, R.L. Implementation of green building specification credits for better thermal conditions in naturally ventilated school buildings. Build. Environ. 2015, 86, 141-150. [CrossRef]

17. Peck, S.W.; Callaghan, C.; Kuhn, M.E.; Bass, B. Greenbacks from Green Roofs: Forging a New Industry in Canada. Status Report on Benefits, Barriers and Opportunities for Green Roof and Vertical Garden Technology Diffusion, Environmental Adaptation Research Group. Prepared for Canada Mortgage and Housing Corporation; Peck \& Associates: Canada, 1999. Available online: https://www.nps.gov/tps/ sustainability/greendocs/peck-sm.pdf (accessed on 30 October 2017).

18. Hall, S.J.; Learned, J.; Ruddell, B.; Larson, K.L.; Cavender-Bares, J.; Bettez, N.; Groffman, P.M.; Grove, J.M.; Heffernan, J.B.; Hobbie, S.E.; et al. Convergence of microclimate in residential landscapes across diverse cities in the United States. Landscape Ecol. 2016, 31, 101-117. [CrossRef]

19. Thatcher, T.L.; Lai, A.C.K.; Moreno-Jackson, M.; Sextro, R.G.; Nazaroff, W.W. Effects of room furnishings and air speed on particle deposition rates indoors. Atmos. Environ. 2002, 36, 1811-1819. [CrossRef]

20. Singer, B.C.; Revzan, K.L.; Hotchi, T.; Hodgson, A.T.; Brown, N.J. Sorption of organic gases in a furnished room. Atmos. Environ. 2004, 38, 2483-2494. [CrossRef]

21. Roulet, C.A.; Foradini, F. Simple and cheap air change rate measurements using carbon-dioxide concentration decays. Int. J. Ventilat. 2002, 1, 39-44. [CrossRef]

22. Asadi, E.; Costa, J.J.; Gameiro da Silva, M. Indoor air quality audit implementation in a hotel building in Portugal. Building Environ. 2011, 46, 1617-1623. [CrossRef] 
23. You, Y.; Bai, Z.; Jia, C.; Wan, Z.; Ran, W.; Zhang, J. Measuring Air Exchanges Rates Using Continuous $\mathrm{CO}_{2}$ Sensors. In Proceedings of the Clima 2007 WellBeing Indoors, Helsinki, Finland, 10-14 June 2007; pp. 101-108.

24. Turanjanin, V.; Vutiaevic, B.; Jovanovic, M.; Mirkov, N.; Lazovic, I. Indoor $\mathrm{CO}_{2}$ measurements in Serbian schools and ventilation rate calculation. Energy 2014, 77, 290-296. [CrossRef]

25. Castleton, H.F.; Stovin, V.; Beck, S.B.M.; Davison, J.B. Green roofs: Building energy savings and the potential for retrofit. Energy Build. 2010, 42, 1582-1591. [CrossRef]

26. ANSI/ASHRAE Standard 55-2004. Thermal Environmental Conditions for Human Occupancy; American society of heating, refrigerating and air-conditioning engineers Inc.: Atlanta, GA, USA, 2004.

27. Pegas, P.; Alves, C.; Evtyugina, M.; Nunes, T.; Cerqueira, M.; Franchi, M.; Pio, C.; Almeida, S.; Freitas, M. Indoor air quality in elementary schools of Lisbon in Spring. Environ. Geochem. Health 2011, 33, 455-468. [CrossRef] [PubMed]

28. Dimitroulopoulou, C. Ventilation in European dwellings: A review. Build. Environ. 2012, 47, 109-125. [CrossRef]

29. Stranger, M.; Potgieter-Vermaak, S.S.; Van Grieken, R. Characterization of indoor air quality in primary schools in Antwerp, Belgium. Indoor Air 2008, 18, 454-463. [CrossRef] [PubMed]

30. Blondeau, P.; Iordache, V.; Poupard, O.; Genin, D.; Allard, F. Relationship between outdoor and indoor air quality in eight French schools. Indoor Air 2005, 15, 2-12. [CrossRef] [PubMed]

31. Morawska, L.; He, C.; Hitchins, J.; Gilbert, D.; Parappukkaran, S. The relationship between indoor and outdoor airborne particles in the residential environment. Atmos. Environ. 2001, 35, 3463-3473. [CrossRef]

32. European Air Quality Standards. Available online: http://ec.europa.eu/environment/air/quality/ standards.htm (accessed on 22 September 2017).

33. Kassomenos, P.; Vardoulakis, S.; Chaloulakou, A.; Grivas, G.; Borge, R.; Lumbreras, J. Levels, sources and seasonality of coarse particles $\left(\mathrm{PM}_{10}-\mathrm{PM}_{2.5}\right)$ in three European capitals-Implications for particulate pollution control. Atmos. Environ. 2012, 54, 337-347. [CrossRef]

34. Alves, C.A.; Urban, R.C.; Pegas, P.N.; Nunes, T. Indoor/Outdoor relationships between PM $_{10}$ and associated organic compounds in a primary school. Aerosol Air Qual. Res. 2014, 14, 86-98. [CrossRef]

35. Fromme, H.; Twardella, D.; Dietrich, S.; Heitmann, D.; Schierl, R.; Liebl, B.; Rüden, H. Particulate matter in the indoor air of classrooms-exploratory results from Munich and surrounding area. Atmos. Environ. 2007, 41, 854-866. [CrossRef]

36. Lee, S.C.; Chang, M. Indoor and outdoor air quality investigation at schools in Hong Kong. Chemosphere 2000, 41, 109-113. [CrossRef]

37. ANSI/ASHRAE Standard 62-1989; Ventilation for Acceptable Indoor Air Quality, Atlanta, American Society of Heating, Refrigerating, and Air Conditioning Engineers Inc.: Atlanta, GA, USA, 1989.

38. Shendell, D.G.; Prill, R.; Fisk, W.J.; Apte, M.G.; Blake, D.; Faulkner, D. Associations between classroom $\mathrm{CO}_{2}$ concentrations and student attendance in Washington and Idaho. Indoor Air 2004, 14, 333-341. [CrossRef] [PubMed]

39. ANSI/ASHRAE Standard 62-2001; Ventilation for Acceptable Indoor Air Quality, American Society of Heating, Refrigerating and Air Conditioning Engineers Inc.: Atlanta, GA, USA, 2001.

40. Raatikainen, M.; Skön, J.P.; Turunen, M.; Leiviskä, K.; Kolehmainen, M. Evaluating Effects of Indoor Air Quality in School Buildings and Students' Health: A Study in Ten Schools of Kuopio, Finland. In Proceedings of the 2nd International Conference on Environment, Energy and Biotechnology (PCBEE), Kuala Lumpur, Malaysia, 8-9 June 2013.

41. Kinney, P.L.; Chillrud, S.N.; Ramstrom, S.; Ross, S.J.; Spengler, J.D. Exposures to multiple air toxics in New York City. Environ. Health Perspect. 2002, 110, 539-546. [CrossRef] [PubMed]

42. Singer, B.C.; Destaillats, H.; Hodgson, A.T.; Nazaroff, W.W. Cleaning products and air fresheners: Emissions and resulting concentrations of glycol ethers and terpenoids. Indoor Air 2006, 16, 179-191. [CrossRef] [PubMed]

43. Yrieix, C.; Dulaurent, A.; Laffargue, C.; Maupetit, F.; Pacary, T.; Uhde, E. Characterization of VOC and formaldehyde emissions from a wood based panel: Results from an inter-laboratory comparison. Chemosphere 2010, 79, 414-419. [CrossRef] [PubMed]

(C) 2018 by the authors. Licensee MDPI, Basel, Switzerland. This article is an open access article distributed under the terms and conditions of the Creative Commons Attribution (CC BY) license (http://creativecommons.org/licenses/by/4.0/). 